Contents lists available at Journal Redwhitepress
Journal of Educational and Learning Studies
ISSN: $2655-2760$ (Print) ISSN: 2655-2779 (Electronic)
Journal homepage: http://journal.redwhitepress.com/index.php/iles

\title{
Development of Problem Based Learning (PBL) practicum guide to improve student Creative Thinking Skills (CTS) in basic physics subject
}

\author{
Desrianti Sahida ${ }^{1}$, Enny Zarvianti ${ }^{2}$ \\ ${ }^{12}$ STKIP Muhammadiyah Sungai Penuh, Indonesia
}

\begin{tabular}{l} 
Article Info \\
\hline Article history: \\
Received May $6^{\text {th }}, 2019$ \\
Revised May $17^{\text {th }}, 2019$ \\
Accepted May $26^{\text {th }}, 2019$
\end{tabular}

\section{Keyword:}

Basic physics

CTS

PBL

Practicum guide

\begin{abstract}
The current study is research and development study, conducted based on observation results obtained from STKIP Muhammadiyah Sungai Penuh. 4-D model was applied in this study. The 4-D model consists of (1) define. Curriculum analysis was conducted, resulting in 48 credits obtained. Analysis on students was conducted, resulting in data revealing that the students' creative thinking skills are still categorized as low. Analysis on subject matters was conducted, resulting in decision to implement the study in Basic Physics I subject matter.(2) design, where the preliminary practicum guide was obtained. (3) development, where the PBL-based practicum guide was categorized as $0.84 \%$ valid, $92.5 \%$ practical, $77 \%$ effective for cognitive aspects, competent for CTS improvements, $80 \%$ creative, $84 \%$ competent for attitudes and $84 \%$ competent for skills (4) dissemination, where the PBL-based practicum guide was categorized as $92 \%$ practical, $76.9 \%$ effective for cognitive aspects, competent for CTS improvements, $70 \%$ creative, $84 \%$ competent for attitudes and $86 \%$ competent for skills.
\end{abstract}

(C) 2019 The Authors. Published by Redwhitepress.

This is an open access article under the CC BY-NC-SA license (https://creativecommons.org/licenses/by-nc-sa/4.0/

\section{Corresponding Author:}

Desrianti Sahida,

STKIP Muhammadiyah Sungai Penuh, Indonesia

Email: dessabki14@gmail.com

\section{Introduction}

Constitution of the Republic of Indonesia No.20 2003 defines education as a deliberate effort for guidance and instructional processes of an individual to become a well-developed, independent, responsible, creative, healthy and well behaved human being. Students' engagement could be observed from their creative activities during learning processes. Learning activities are directed at empowering all potential students to become the expected competencies (Depdiknas, 2006). Creativity is considered as products generated by creative thinking; a skill of thinking and finding out new knowledge; generating new suggestions by combining, replacing or implementing existed idea. Accordingly, creative activities are activities in learning directed to support or stimulate students' creativity.

The Great Dictionary of the Indonesian Language (KBBI) defines creativity as potentially having skills to create. (Gunawan, 2006) defines creative thinking as skills to use complicated thinking structures in order to generate a new and original idea. Creative thinking skill or CTS is a cognitive skill to generate and develop new suggestions, new idea developed from previous idea; CTS is a skill to find our problems from many various perspectives. Students' spectrum in CTS is able to be measured. To have creative skill, student should find problem first (Nuraida, 2017). Result of the student work in upper category, show that they can 
understand the given problem well (Maharani, n.d.). Students who have high creative thinking skills see a problem from various possibilities (Nursofah, Komala, \& Rusdi, 2018). According to (Siswono \& Abadi, 2010), increasing CTS is parallel to increasing students' skills in understanding problems; fluency, flexibility and problem solving. Fluency is an indicator with a low increase compared to the other indicators, Flexibility the ability to generate answers in several ways while, Originality is the ability to give birth to new ideas (Arvyati, n.d.). (Greenstein, 2012) explain creative thinking skills indicators are Curiosity, Fluency, Originality, Elaboration, Flexibility, Imagination. Creative Thinking Skill Indicator According to (Munandar, 1986) are Fluency, Originality, Elaboration, Flexibility. Based on the explanation of several creative thinking skills indicators, D. Sahida (2018) concluded that, creative thinking skills are a person's ability to give birth to something new, both in the form of ideas and real work that are different from those that already exist. Giving scores or measurements of creative student thinking skills based on indicators from four components of creative thinking skills, namely fluency, flexibility, originality, and elaboration.

Need analysis conducted on lecturers reveals that Basic Physics I learning processes have been implemented effectively. However, analysis conducted on students reveals that students' CTS in Basic Physics I is still categorized as low. The low students' CTS is indicated by scores obtained from the students in answering every CTS indicator, where the total results were less than $60 \%$. The students' low CTS might be due to the lack of competent practicum guide to improve the students' CTS. PBL is an instructional model to encourage students to be actively and creatively engaged with real world problems. PBL process is really student centered learning (Isrokijah, 2016). PBL is focused on the development of students learning and not to help the teacher gather information that will be given to students during the learning process (Sari \& Masruri, 2018). PBL in the learning effect on the cognitive abilities of students (Pujayanto, Supurwoko, Radiyono, \& Adi, 2017). The learning model of PBL method within demonstration method has more influence on students' problem-solving ability than without demonstration method (Riswari, Yanto, \& Sunarso, 2018). Problem Based Learning step is like how it is stated in lesson plan, the learning method also got positive response from the students (Yuliana \& Firmansah, 2018). (Abidin, 2014) defines PBL steps as followed: (a) Finding out problems, (b) Finding out work structures, (c) Embarking on problems, (d) Gathering and sharing information, (e) Finding out solutions, (f) Deciding best solutions, (g) Providing solutions. Symons (2005) defines PBL steps as followed:(a) Clarify, (b) Define, (c) Analyze, (d) Review, (e) Identify Learning Objectives, (f) Self Study, (g) Report and Synthesis. By using the PBL model there is an increase in the results of creative thinking skills (knowledge competencies) (Sahida, 2018). PBLmodel could potentially give students more meaningful new experiences and knowledge through existed problem solving. This way, students' CTS could be improved. Thus, the students' low CTS skill as noted to be the problems portrayed in Physics Education department could be solved by integrating PBL model in practicum guides.

\section{Method}

The current study is research and development. Development methods applied is 4-D model, consists of at least four steps: define, design, development and disseminate. Define step of the model resulting in 48 credits obtained. Analysis on students was conducted, resulting in data revealing that the students' creative thinking skills in Basic Physics 1 are still categorized as low. Data analysis techniques applied was descriptive analysis portraying validity, practicality and efficacy of PBL-based practicum guide.

\section{Results and Discussion}

\section{Stage 1: Define}

Define is the fundamental stage of the PBL-based practicum guide development to improve the students' CTS in Basic Physics I. In case there is an incompatibility between the PBL-based practicum guide with the learning goals of Basic Physics 1 curriculum, the incompatible elements will be developed in further.

\section{Stage 2: Design}

Subsequent to defining, design stage on the PBL-based practicum guide to improve the students' CTS took place. In the initial step of designing, practicum guide scripts were created as shown in Figure 1. Afterwards, the PBL-based practicum guide and CTS indicator fulfillment were designed as shown in Figure 2 . 


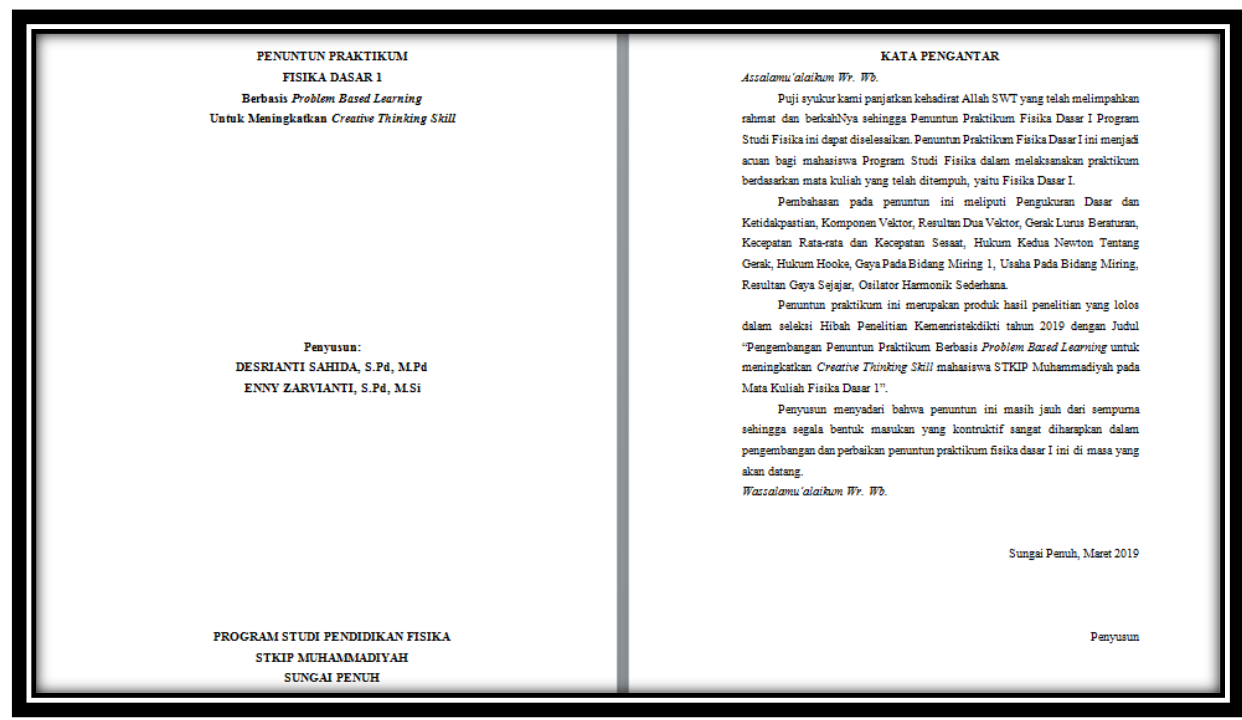

Figure 1.PBL-based practicum guide script for CTS improvements in Basic Physics I subject

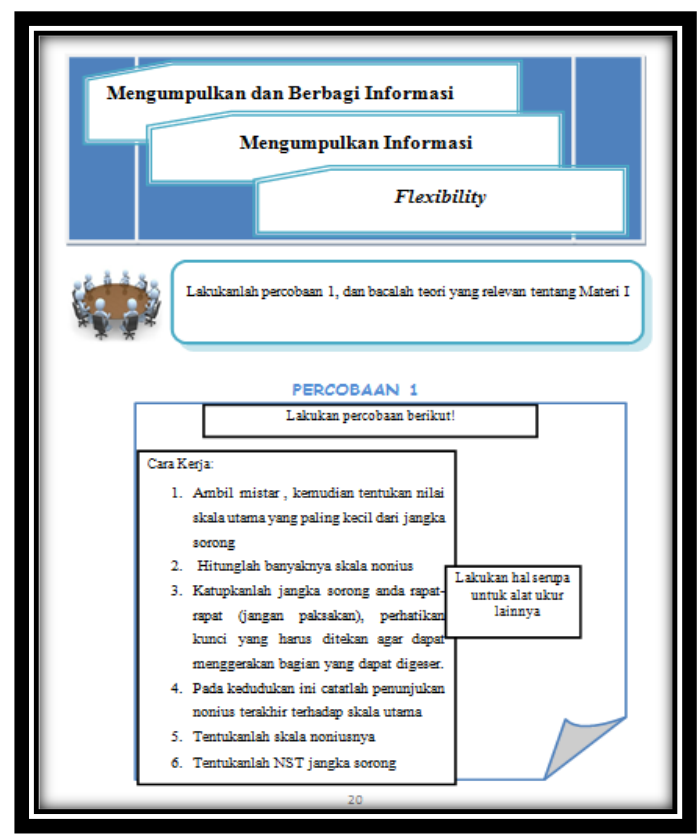

Figure 2.PBL-based practicum guide with CTS indicator fulfillment

\section{Stage 3: Development}

Practicum Guide Validation

Following the define and design stage, the PBL-based practicum guide was validated by three experts from STKIP Muhammadiyah Sungai Penuh.In this stage, the validators were asked to give scores to the PBLbased practicum guide. The scoring includes content validity, construction and language. The PBL-based practicum guide development results are as shown in Table 6.

Table 6. Validation Results of PBL-Based Practicum Guide

\begin{tabular}{cccc}
\hline No & \multicolumn{1}{c}{ Validation Indicators } & Validation Results & Category \\
\hline $\mathbf{1}$ & Content & & Valid \\
& a. Practicum guide component & 0,83 & Valid \\
$\mathbf{2}$ & b. Content appropriateness & 0,84 & Valid \\
$\mathbf{3}$ & Lonstruction & 0,84 & Valid \\
\hline
\end{tabular}


Thus, the PBL-based practicum guide for CTS improvements in Basic Physics I subject is appropriate to be implemented in classroom lectures. After the completion of validation processes, pilot test was implemented in STKIP Muhammadiyah Sungai Penuh. The pilot test was implemented 16 times with the results as explained below: 1) questionnaire with lecturers' responses, lecturers' perspectives on the developed PBL-based practicum guide for CTS improvements in Basic Physics I obtained average score of 93\%. Based on practicality category interval, the score is categorized as very practical. Thus, the respondents perceive that the PBL-based practicum guide is very practical for CTS improvements. Beside, the practicum guide reduces difficulties faced by the lecturers in delivering Basic Physics I subject with its practicality; 2) questionnaire with students' responses, student questionnaire was given to all the students in the experiment class in order to find out practicality rate of the PBL-based practicum guide for CTS improvements. The questionnaires were delivered to twenty one students in every meeting. Analysis results of the questionnaires revealed that the developed PBL-based practicum guide achieved average score of $92 \%$, indicating the practicum guide is categorised as very practical.

\section{Practicum Guide Efficacy}

1) knowledge scoring results, the students' knowledge competence data was gathered from written tests conducted in every meeting. Results from the first until sixteenth meeting are exercise score results on evaluation sheets. The students' average score during the sixteen meetings is 77 . There is an improvement in the students' competence knowledge in every meeting. Thus, it is proven that the PBL-based practicum guide could enhance the students' academic scores in knowledge competence; 2) students' attitude analysis results, the students' attitude analysis results were obtained from observations on the students' attitude during learning processes. Data gathered from respondent sheets were filled by the observers in order to observe the students' attitude during the learning processes. Overall, the students' attitudes were categorized as 'very good', achieving a percentage of $84 \%$. In other words, the developed practicum guide is effective for learning processes. In relation, an assumption could be made that the students' habit could be positively influenced through using the practicum guide. Thus, the practicum guide implementation could potentially contribute to the improvements of the students' attitude; 3) skills' scoring results, observation results on skill competence were taken from the students' activities during practicum. Overall, the students' skills are noted as 'very good', with the average percentage of $84 \%$. Despite the students generally achieve 'very good' category, but the total score for every meeting is fluctuating; 4) CTS improvement analysis results, CTS improvement results were obtained from knowledge evaluation results. Obvious CTS improvements could be portrayed essays about Basic Physics I. In order to portray CTS improvements, pre-test and post-test were conducted before and after research implementation. The students' CTS average score raised gradually across each meeting. Despite the students' average score in the first is categorized as lacking in creativity, but the percentage measured in the next several meetings raised gradually. Overall, the students are categorized as "significantly creative". At the same token, the passing grade for basic Physics I subject was also gradually increased. in the final meeting, $100 \%$ of the students were able to pass the subject passing grade.

\section{Stage 4: Dissemination Stage}

Distribution Instrument Practicality

The purposes of dissemination stage are to portray both practicality and efficacy of the practicum guide when it is disseminated to classes or larger and wider groups. Dissemination in the first meeting was conducted subsequent to the revision after pilot study in the first meeting conducted, these identical steps were then repeated four the next several meetings. Lecturer processes in dissemination stage were parallel with the lecturer processes conducted in the pilot study. In this research, dissemination stage was restricted to be implemented only on one class in one university. Dissemination stage was implemented in Class B of Physics Education Study Program STKIP Sungai Penuh.

\section{Practicality Results of Lecturers' Response Questionnaire}

Lecturers' perspectives in the dissemination class on the developed practicum guide achieve a percentage of $97 \%$ in average. According to the intervals, the percentage obtained is defined as "significantly practical". Thus, the respondents perceive that the developed practicum guide is significantly practical so that the guide is considered to be helpful for lecturers to use in Basic Physics I subject.

\section{Practicality Results of Students' Responses Questionnaire}

In dissemination stage, practicality test was conducted to seek practicality of the developed practicum guides when the guides were distributed to other classes. Practicality test results in dissemination stage reveal that the students' responses result to a percentage of $92 \%$ in average. The percentage obtained indicates that the developed practicum guide is proven to be practical to use in other classes/ 
Development of Problem Based Learning (PBL) practicum guide to improve student Creative

Thinking Skills (CTS) in basic physics subject

\section{Practicum Guide Efficacy}

1) knowledge scoring results, the students' knowledge competence data was gathered from written tests conducted in every meeting. Results from the first until sixteenth meeting are exercise score results on evaluation sheets. The students' average score during the sixteen meetings is 76. The students' average score has received the passing grade; 2) students' attitude analysis results, the students' attitude analysis results in disseminations stage were obtained from respondent sheets which were filled by the observers in order to portray the students' attitude during the learning processes. Overall, the students' attitudes were categorized as 'significantly good', achieving a percentage of $84 \%$. In other words, the developed practicum guide is effective for learning processes.There are improvements on the students' attitude from the first until final meeting. Thus, it is proven that the developed practicum guides are able to be used in other classes; 3) skills' scoring results, the students' results on skill competence were gathered from the students' activities when doing researches. The class where dissemination stage took place and the class where pilot study took place were both conducting the same experiment. The students' skills are generally noted as 'significantly good', with a percentage of $86 \%$. There are improvements on the students' skill competence in every meeting. Thus, it is proven that the developed practicum guides are able to increase skill competence of students in other classes; 4) CTS improvement analysis results, similar to the class in pilot study, the class in dissemination stage conducted the same techniques to portray CTS improvements. The students' CTS improvements are categorized as "significantly creative". Despite the fact that there was no CTS improvement as measured using gain score were not in the first until third meeting. However, there was an increase in the average score of academic achievements and classical passing grade percentages within the three days meeting.

\section{Conclusion}

The PBL-based practicing guide for students' CTS improvements in Basic Physics I had been developed through four stages: define, design, develop, and dissemination. The development results of PBL-based practicum guide obtained outstanding criteria on validity, practicality and efficacy. The practicum guide achieved average score of 0.84 for its validity, categorized as valid. The practicum guide achieved average score of 92.5 for its practicality, categorized as practical. There was an improvements on the students' knowledge competence CTS results, attitudes and skills in every meeting, indicating that the developed practicum guide is effective for classroom implementation. The dissemination stage of the practicum guide was conducted by disseminating the practicum guide to other Basic Physics I classes. The practicum guide's practicality test results scored 92, categorized as practical. There was an improvements on the students' knowledge competence CTS results, attitudes and skills in every meeting, indicating that the developed practicum guide is effective for more comprehensive classroom implementation.

\section{Acknowledgement}

I would like to address his gratitude to KEMENRISTEK DIKTI who have been financially supporting this research. I would also like to include a special note of thanks to the Institutional President, lecturers and stakeholders of STKIP Muhammadiyah Sungai Penuh who have been giving their supports for the completion of this research.

\section{References}

Abidin, Y. (2014). Desain sistem pembelajaran dalam konteks kurikulum 2013. Refika Aditama.

Arikunto, S. (1999). Dasar-dasar evaluasi pendidikan. Bumi Aksara.

Arvyati, I. (n.d.). M., \& Irawan, A.(2015). Effectivity Of Peer Tutoring Learning To Increase Mathematical Creative Thinking Ability Of Class XI IPA SMAN 3 KENDARI 2014. International Journal of Education and Research, 3(1), 613-628.

Depdiknas, P. K. B. (2006). Kurikulum tingkat satuan pendidikan. Jakarta: Depdiknas.

Greenstein, L. M. (2012). Assessing 21st century skills: A guide to evaluating mastery and authentic learning. Corwin Press.

Gunawan, A. W. (2006). Genius learning strategy. Jakarta: Pustaka Utama.

Isrokijah, I. (2016). Developing Problem-Based Learning (PBL) Worksheets for the Eight Grade Students at Junior High School. LLT Journal: A Journal on Language and Language Teaching, 18(2), 99-106.

Khoiri, N., Riyadi, S., Kaltsum, U., Hindarto, N., \& Rusilawati, A. (2017). Teaching Creative Thinking Skills with Laboratory Work. International Journal of Science and Applied Science: Conference Series, 2(1), 256-260.

Maharani, H. R. (n.d.). Sukestiyarno and Waluya B 2017 Creative thinking process based on Wallas model in solving mathematics problem. International Journal on Emerging Mathematics Education, 1(2), 177184. 
Munandar, S. C. U. (1986). Mengembangkan bakat dan kreativitas anak sekolah: petunjuk bagi para guru dan orang tua. Gramedia.

Nuraida, N. (2017). The Effect of Creative Teaching Technique to Creative Problem-Solving Ability in Students. TARBIYA: Journal of Education in Muslim Society, 4(1), 53-62.

Nursofah, N., Komala, R., \& Rusdi, R. (2018). The Effect of Research Based Learning Model and Creative Thinking Ability on Students Learning Outcomes. Indonesian Journal of Science and Education, 2(2), 168-173.

Pujayanto, P., Supurwoko, S., Radiyono, Y., \& Adi, D. W. (2017). Development of problem-based learning material for physics mathematics and its implementation. International Journal of Science and Applied Science: Conference Series, 1(1), 16-24.

Reliabilitas, A. S. (2015). Validitas. Pustaka Pelajar.

Riduwan, D. (n.d.). MBA 2010. Dasar-Dasar Statistika.

Riswari, L. A., Yanto, H., \& Sunarso, A. (2018). The Effect of Problem Based Learning by using Demonstration Method on The Ability of Problem Solving. Journal of Primary Education, 7(3), 356362.

Sahida, D. (2018). Pengembangan Lembar Kerja Peserta Didik Berbasis Problem Based Learning Berbantuan Komik untuk Meningkatkan Creative Thinking Skill Peserta Didik pada Materi Gerak Lurus. JURNAL EKSAKTA PENDIDIKAN (JEP), 2(1), 9-16.

Sari, N. H. Y., \& Masruri, M. S. (2018). The effectiveness of project-based learning and problem-based learning models towards geography learning outcomes in terms of students'locus of control. Geosfera Indonesia, 3(3), 16-25.

Siswono, T. Y. E., \& Abadi, A. H. R. (2010). Pengembanagan Model Pembelajaran Matematika Berbasis Pengajuan dan Pemecahan Masalah Untuk Meningkatkan Kemampuan berpikir Kreatif Siswa Sekolah Dasar. Widya Cendika, 5(1).

Yuliana, Y., \& Firmansah, F. (2018). The effectiveness of problem-based learning with social media assistance to improve students'understanding toward statistics. Infinity Journal, 7(2), 97-108. 